\title{
Gaya Bahasa Pada Lirik Lagu Spirits Of The Sea Karya Kenshi Yonezu
}

\author{
Zaki Ainul Fadli*, Dewi Kusmiati \\ Program Studi Bahasa dan Kebudayaan Jepang Universitas Diponegoro \\ *Email: zakiaf@live.undip.ac.id
}

\begin{abstract}
Abstrak
Lirik dari sebuah lagu merupakan curahan perasaan pribadi penulisnya dan mengandung berbagai makna berdasarkan gaya bahasa yang digunakan. Gaya bahasa dalam sebuah karya sastra tersebut dikenal dengan istilah 'stilistika'. Sehubungan dengan hal tersebut, tujuan penelitian ini untuk mengetahui unsur-unsur stilistika (gaya bahasa) yang terdapat dalam lirik lagu Spirits of the Sea karya Kenshi Yonezu. Teori yang digunakan adalah teori gaya bahasa Gorys Keraf. Dalam melakukan penelitian ini, penulis menggunakan metode kualitatif. Teknik pengolahan data yang digunakan adalah teknik telaah pustaka dan teknik analisis. Data diperoleh dengan cara membaca lirik lagu Spirits of the Sea karya Kenshi Yonezu. Melalui metode teknik telaah pustaka dan teknik analisis, hasil dan simpulan yang didapatkan berupa data kualitatif yang berupa uraian dan penafsiran, yaitu gaya bahasa berdasarkan pilihan kata yang digunakan dan gaya bahasa berdasarkan struktur kalimat dalam lirik lagu Spirits of the Sea karya Kenshi Yonezu. Selain itu, setelah dianalisis terdapat beberapa jenis gaya bahasa berdasarkan langsung tidaknya makna dalam lirik lagu Spirits of the Sea karya Kenshi Yonezu, seperti personifikasi, hiperbola, dan lain sebagainya.
\end{abstract}

\section{Keywords: Stilistika; Spirits of the Sea; Kenshi Yonezu}

\begin{abstract}
(Title: Stylistics on Song Lyrics Spirits of the Sea by Kenshi Yonezu) Lyrics of the song are an outpouring of the author's personal feelings and contain various meanings based on the style of language used. The style of language in a literary work is known as the 'stylistics'. In this regard, this research trying to find out the stylistic elements (language style) contained in the lyrics of Spirits of the Sea by Kenshi Yonezu. The theory used is the style theory by Gorys Keraf. In conducting this research, the author uses qualitative methods. Data processing techniques used are literature review and analysis techniques. Data obtained by reading the lyrics of the song Spirits of the Sea by Kenshi Yonezu. Through library research methods and analysis techniques, the results and conclusions obtained in the form of qualitative data is description and interpretation, namely the style of language based on the choice of words used and the style of language based on the sentence structure in the lyrics. Besides, there are several types of language styles based on the direct or indirect meaning in the lyrics of the song Spirits of the Sea by Kenshi Yonezu such as personification, hyperbole, etc.
\end{abstract}

Keywords: Stylistics; Spirits of the Sea; Kenshi Yonezu 


\section{PENDAHULUAN}

Kata sastra secara etimologis berasal dari bahasa Sanskerta. 'Sas' berarti mengajar, mengarahkan, memberi petunjuk atau instruksi dan 'tra' yang berarti alat atau sarana. Dapat disimpulkan bahwa sastra adalah alat atau sarana dalam mengajar. Karya sastra bersifat fiktif, walaupun didasarkan pada kehidupan nyata. Hal ini dikarenakan ide yang dituangkan dalam karya sastra sudah diolah terlebih dahulu oleh pengarang. Makna sastra bersifat kontekstual, bergantung pada konsep atau pandangan yang berlaku pada masyarakat tertentu. Genre sastra biasanya terdiri atas puisi, prosa, dan drama. Namun, perkembangan sastra modern sekarang ini meliputi komik strip, film, anime, iklan, dan lirik lagu terlepas dari melodinya.

Lirik lagu termasuk ke dalam karya sastra puisi karena pada dasarnya lirik lagu tersebut diadopsi dari satuan lirik-lirik yang dapat disebut dengan puisi. Sebuah lirik bisa menjadi lagu karena mengalami proses estetika, yaitu proses meluapkan isi hati pada secarik kertas dengan kata-kata. Setelahnya, bait-bait tersebut disatukan, disesuaikan dengan nada atau melodi, kemudian menjadi sebuah lagu yang bisa dinikmati. (Noor, 2015)

Spirits of the Sea atau 海の幽霊 adalah sebuah lagu karya Kenshi Yonezu. Lagu ini dirilis pada tanggal 3 Juni 2019 dengan durasi 3 menit 54 detik di bawah label Sony Music Records/Mastersix Foundation. Lirik dari Spirits of the Sea ditulis oleh Kenshi Yonezu, seorang penyanyi sekaligus penulis lirik, produser, dan ilustrator.

Salah satu penelitian dengan pendekatan stilistika yang sudah ada dengan objek penelitian lirik lagu "Home Sweet
Home" karya Yuki Ishoya menggunakan teori gaya bahasa dalam bahasa Jepang menurut Nakamura Akira melalui journal Japanlogy (2008: 27-29) meliputi : Simile (直 喻 chokuyu), alegori (諷喻 fuuyu), alusio (引喻 inyu), hiperbola (張喻 chouyu); menurut Shigeko Inagaki melalui journal Japanlogy (2016: 30-32), meliputi: Klimaks (ぜんそほう zenzou), epizeuksis (反復法 hanpukuhou). Sedangkan menurut Seto Kenichi melalui jurnal Japanlogy (2016: 32-34), membagi gaya bahasa atas: metafora (隠喻 in'yu), oksiromon (同着法 douchakuhou), eupimisme (婉曲法 enkyokuhou), paradoks (逆説法 gyakusetsuhou) (Marantika, 2017).

Sedangkan dalam penelitian ini dianalisis objek karya sastra berupa lirik lagu Spirits of the Sea karya Kenshi Yonezu dengan menggunakan teori gaya bahasa Gorys Keraf.

Dalam Kamus Besar Bahasa Indonesia 'Stilistika' diartikan sebagai ilmu tentang penggunaan bahasa dan gaya bahasa di dalam karya sastra. Stilistika sudah mulai dikenal sejak ratusan tahun yang lalu, kata stilistika secara etimologis berasal dari Bahasa Inggris yang dikenal dengan istilah stylistic. Kata stylistic berasal dari dua kata, yaitu kata style dan kata istic. Kata style berarti gaya sedangkan kata istic berarti ilmu. Jadi kata Stylistic dalam bahasa Inggris dapat diartikan sebagai Ilmu Gaya Bahasa.

A. Teeuw menegaskan bahwa stilistika pada prinsipnya selalu meneliti pemakaian gaya bahasa yang khas atau istimewa, yang merupakan ciri khas seorang penulis aliran sastra dan lain-lain yang menyimpang dari bahasa sehari-hari atau yang dianggap normal. (Zulqarnain, n.d.). Menurut teori gaya bahasa Gorys Keraf, terdapat tiga jenis gaya bahasa, yaitu (1) gaya bahasa berdasarkan pilihan kata, (2) gaya bahasa berdasarkan struktur 
kalimat, dan (3) gaya bahasa berdasarkan langsung tidaknya makna (Keraf, 2007).

Tujuan penulisan artikel ini adalah untuk mengetahui unsur-unsur stilistika (gaya bahasa) yang terdapat dalam lirik lagu Spirits of the Sea karya Kenshi Yonezu.

\section{METODE}

Metode yang digunakan dalam penelitian ini adalah teknik telaah pustaka dan teknik analisis.

a. Teknik telaah pustaka

Teknik telaah pustaka merupakan metode penelitian dengan cara mengkaji secara kritis atas pembahasan suatu topik yang sudah ditulis oleh para peneliti atau tokoh yang terakreditasi dalam bidangnya. (Swadiyana, n.d.)

b. Teknik analisis

Teknik analisis yang dilakukan adalah analisis data secara kualitatif, dengan menganalisis unsur stilistika pada lirik lagu Spirits of the Sea karya Kenshi Yonezu, kemudian dilakukan uraian dan penafsiran (Yuliantini, Yanti D., \& Putra, 2017).

\section{HASIL DAN PEMBAHASAN}

\subsection{Gaya Bahasa Berdasarkan Pilihan Kata}

Gaya bahasa yang digunakan dalam lirik lagu Spirits of Sea adalah gaya bahasa tidak resmi. Hal ini ditandai dengan pilihan kata seperti yang dapat dilihat pada tabel 1 baris ke-1 誰もいない (daremo inai), baris ke-6 何から話せばいいのか (nani kara hanaseba ii no ka), dan baris ke-7 わ力らな くなるかな (wakaranaku naru ka na), dan masih banyak lagi lainnya. Bentuk -nai, -no ka, dan -ka na tersebut menandakan bahwa pilihan kata yang digunakan adalah futsuukei atau bentuk biasa. Penggunaan futsuukei atau bentuk biasa dalam bahasa Jepang memberikan kesan hubungan yang dekat antara pembicara dengan lawan bicara, seperti hubungan pertemanan atau kekeluargaan. 
Kiryoku, Volume 4 No 12020

e-ISSN: 2581-0960 p-ISSN: 2599-0497

Tersedia online di http://ejournal.undip.ac.id/index.php/kiryoku

\begin{tabular}{|c|c|c|}
\hline Baris & Teks asli & Terjemahan \\
\hline 1 & 開け放たれた この部屋には誰もいない & Tak ada seorang pun di ruangan yang terbuka ini \\
\hline 2 & 潮風の匂い＼cjkstart染み付いた椅子がひとつ & Hanya ada sebuah kursi yang beraroma angin laut \\
\hline 3 & & \\
\hline 4 & あなたが迷わないように開けておくよ & Aku membiarkannya terbuka agar kau tak tersesat \\
\hline 5 & 軋む戸を叨いて & Sementara membuat suara decitan \\
\hline 6 & 何から話せばいいのか & Apakah yang sebaiknya kubicarakan? \\
\hline 7 & わからなくなるかな & Mungkinkah aku kehilangan arah? \\
\hline 8 & & \\
\hline 9 & 星が降る夜に あなたにあえた & Di malam dengan hujan bintang, aku bertemu dirimu \\
\hline 10 & あの夜を忘れはしない & Aku takkan pernah melupakan malam itu \\
\hline 11 & 大切なことは 言葉にならない & Hal yang berharga tak dapat menjadi kata-kata \\
\hline 12 & 夏の日に起きたすべて & Segalanya yang terjadi di musim panas \\
\hline 13 & & \\
\hline 14 & 思いがけず＼cjkstart光るのは & Cahaya yang tanpa diduga itu \\
\hline 15 & 海の幽霊 & Adalah hantu laut \\
\hline 16 & & \\
\hline 17 & うだる夏の夕に＼cjkstart梢が船を見送る & Melihat kepergian kapal saat musim panas \\
\hline 18 & いくつかの歌を囁く 花を散らして & Aku menyanyikan entah berapa lagu dan menaburkan \\
\hline 19 & & bunga-bunga \\
\hline 20 & あなたがどこかで笑う声が聞こえる & Aku bagai mendengar suara tawamu di suatu tempat \\
\hline 21 & 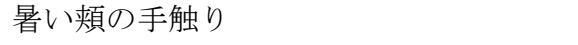 & Sementara merasakan pipi yang hangat \\
\hline 22 & ねじれた道を進んだら & Jika aku terus maju di jalan memutar itu \\
\hline 23 & その瞼が開く & Maka mata ini pun akan terbuka \\
\hline 24 & & \\
\hline 25 & 離れ離れでも ときめくほど & Meski kita terpisah, waktu akan tetap datang \\
\hline 26 & 叫ぼう「今は幸せ」と & Mari meneriakkan "sekarang aku bahagia" \\
\hline 27 & 大切なことは＼cjkstart言葉にならない & Hal yang berharga tak dapat menjadi kata-kata \\
\hline 28 & 跳ねる光に溶かして & Hilang di dalam cahaya yang memantul \\
\hline 29 & & \\
\hline 30 & 星が降る夜に あなたにあえた & Saat hujan bintang, aku bertemu denganmu \\
\hline 31 & あの時を忘れはしない & Aku takkan pernah melupakan waktu itu \\
\hline 32 & 大切なことは 言葉にならない & Hal yang berharga tak dapat menjadi kata-kata \\
\hline 33 & 夏の日に起きたすべて & Segalanya yang terjadi di musim panas \\
\hline 34 & & \\
\hline 35 & 思いがけず & Cahaya yang tanpa diduga itu \\
\hline 36 & 海の幽霊 & Adalah hantu laut \\
\hline 37 & & \\
\hline 38 & 風薰る 砂浜で & Aroma angin di pasir pantai \\
\hline 39 & また会いましょう & Mari bertemu Kembali \\
\hline
\end{tabular}

Tabel 1 Lirik Lagu Spirits of the Sea

(Sumber: http://j-lyric.net/artist/a0579b7/104bfd1.html

Copyright @2020, KIRYOKU, e-ISSN:2581-0960p-ISSN: 2599-0497 


\subsection{Gaya Bahasa Berdasarkan Struktur Kalimat}

Berdasarkan lirik pada tabel 1 baris 17 sampai ke-39 di atas, gaya bahasa yang digunakan adalah gaya bahasa klimaks. Lirik tersebut mengandung urutan gagasan yang semakin meningkat tingkat kepentingannya. Urutan kalimat pada lirik lagu dari awal hingga akhir membentuk suatu alur atau plot yang puncaknya ada pada bagian chorus (mulai baris ke -9), yang ditutup pada baris ke-15 dengan katakata 海の幽霊 (umi no yuurei). Hal itu kemudian diulang pada baris ke-30 sampai 36.

\subsection{Gaya Bahasa Berdasarkan Langsung Tidaknya Makna}

Lirik:

何から話せばいいのか

わからなくなるかな

Romaji:

Nani kara hanaseba $\overline{1}$ no ka

Wakaranaku naru ka na

Terjemahan:

Apakah yang sebaiknya kubicarakan?

Mungkinkah aku menjadi tidak mengerti?

Lirik di atas menggunakan gaya bahasa retorik karena merupakan sebuah pertanyaan yang jawabannya sudah terkandung dalam pertanyaan tersebut. (Dinata, n.d.)

Kanji:

星が降る夜に あなたにあえた あの時を忘れはしない

大切なことは 言葉にならない

夏の日に起きたすべて

Romaji:

Hoshigafuru yoru ni anata ni aeta Ano toki o wasure wa shinai
Taisetsu na koto wa kotoba ni naranai Natsu no hi ni okita subete

Terjemahan:

Seperti hujan bintang, aku ingin bertemu denganmu

Aku takkan pernah melupakan waktu itu Hal yang berharga tak dapat menjadi katakata

Segalanya yang terjadi di musim panas

Lirik di atas adalah jawaban dari kalimat dengan gaya bahasa retorik di atas. Hal yang ingin dikatakan sebenarnya adalah mengenai suatu kenangan pada malam musim panas.

Lirik:

うだる夏の夕に 梢が船を見送る 離れ離れでも ときめくほど

Romaji:

Udaru natsu no yūbe ni kozue ga fune o miokuru

Hanare banare demo tokimeku hodo Terjemahan:

Bagaikan puncak bukit yang melihat kepergian kapal saat musim panas

Meski kita terpisah, waktu akan tetap datang

Lirik うだる夏の夕に 梢が船を見 送るdan 離れ離れでもときめくほど menggunakan gaya bahasa personifikasi karena menggambarkan perumpamaan suatu benda seperti manusia melalui kalimat "puncak bukit yang melihat kepergian kapal" dan "waktu akan tetap datang". (Karsana, n.d.)

Lirik:

星が降る夜に あなたにあえた

Romaji: 
Hoshigafuru yoru ni anata ni aeta Terjemahan:

Di malam dengan hujan bintang, aku bertemu denganmu

Lirik di atas menggunakan gaya bahasa ironi karena makna dari kalimat tersebut berlainan dari apa yang terkandung dalam rangkaian kata-katanya. Kalimat 星が降る 夜に berarti hujan bintang, yang memiliki kesan tidak aman dan nyaman. Kemudian pada kalimat あなたにあえた yang berarti aku bertemu denganmu, mengindikasikan keberuntungan yang dialami oleh pengarang terlepas dari kesan tidak aman dan nyaman yang tergambar di kalimat sebelumnya.

Lirik:

開け放たれた この部屋には誰もいな い

Romaji:

Akehanata reta kono heya ni wa daremoinai

Terjemahan:

Tak ada seorang pun di ruangan yang terbuka ini

Lirik di atas menggunakan gaya bahasa paradoks karena mengandung pertentangan dengan fakta yang ada. Kalimat 開け放たれた berarti ruangan yang terbuka. Sebuah ruangan terbuka akan memiliki kesan ramai karena mudah dijangkau. Namun, kalimat selanjutnya $こ$ の部屋には誰もいない yang berarti taka da seorang pun, menunjukkan pertentangan dengan kalimat sebelumnya.

Lirik:

叫ぼう「今は幸せ」と

Romaji:

Sakebou "ima wa shiawase" to

Terjemahan:

Mari meneriakkan "sekarang aku bahagia"
Lirik lagu di atas menggunakan gaya bahasa apostrof karena mengandung pengalihan amanat atau pesan yang disampaikan kepada sesuatu yang abstrak dan bersifat khayalan. Objek pembicaraan pengarang dalam keseluruhan lirik adalah sesuatu yang abstrak, seperti pada kalimat あなたがどこかで笑う声が聞こえる (aku bagai mendengar suara tawamu di suatu tempat) dan 思いがけず光るのは 海の幽霊 (cahaya yang tanpa diduga itu adalah hantu laut).

\section{SIMPULAN}

Hasil analisis unsur stilistika dalam lirik lagu Spirits of the Sea karya Kenshi Yonezu, dapat diperoleh simpulan sebagai berikut: 1) Gaya bahasa berdasarkan pilihan kata yang digunakan dalam lirik lagu Spirits of Sea adalah gaya bahasa tidak resmi; 2) Gaya bahasa berdasarkan struktur kalimat yang digunakan dalam lirik lagu Spirits of the Sea adalah gaya bahasa Klimaks; 3) Terdapat beberapa jenis gaya bahasa berdasarkan langsung tidaknya makna dalam lirik lagu Spirits of the Sea, yaitu (1) retorik, (2) personifikasi, (3) ironi, (4) paradoks, dan (5) apostrof.

Penelitian mengenai lagu Spirits of the Sea ini masih mungkin dikembangkan, khususnya dalam hal pemaknaan lagu, karena dalam lagu ini terdapat lirik yang memiliki makna konotatif yang memungkinkan untuk dilakukannya penelitian lebih lanjut.

\section{REFERENSI}

Dinata, C. (n.d.). Stilistika dan Karya Sastra. Retrieved from https://www.academia.edu/10502734/ Stilistika_dan_Karya_Sastra

Karsana, A. (n.d.). Bahasa dan Gaya 
Bahasa (Stilistika). Retrieved from http://file.upi.edu/Direktori/FPBS/JU R._PEND._BAHASA_DAERAH/194 711101975011ANO_KARSANA/Bahasa_dan_Gaya _Bahasa_Drs._Ano_Karsana\%2C_ M.Pd..pdf

Keraf, G. (2007). Diksi dan gaya bahasa. Jakarta: Gramedia Pustaka Utama.

Marantika, A. C. (2017). Kajian Stilistika Berunsur Budaya Dalam Lirik Lagu "Home Sweet Home" Karya Yuki Ishoya (Universitas Diponegoro). Retrieved from http://eprints.undip.ac.id/51759/1/Skri psi_Full.pdf

Noor, R. (2015). Pengantar Pengkajian
Sastra. Semarang: FASindo.

Swadiyana, E. (n.d.). Lecture Telaah Pustaka. Retrieved from https://www.scribd.com/document/10 9153428/04-Lecture-Telaah-Pustaka

Yuliantini, Yanti D., \& Putra, A. W. (2017). Semiotika Dalam Novel Rembulan Tenggelam Di Wajahmu Karya Tere Liye. Jurnal Literasi, 1, 65-68.

Zulqarnain, I. (n.d.). Stilistika Sastra Indonesia. Retrieved from https://www.scribd.com/doc/2101644 55/Stilistika-Sastra-Indonesia 